\title{
Energy use project and conversion efficiency analysis on biogas produced in breweries
}

\author{
LI Yingjian ${ }^{1, *}$, QIU Qi ${ }^{1}$, HE Xiangzhu ${ }^{2}$, LI Jiezhi $^{3}$ \\ ${ }^{I}$ College of Chemistry \& Chemical Engineering, Shenzhen University, 518060, Shenzhen, PR China. \\ ${ }^{2}$ Hunan Energy Conservation Center, 410007 Changsha, PR China \\ ${ }^{3}$ Ecole centrale de Lyon, 69130, Lyon, France. \\ *Corresponding author.Tel.:+86 755-26538802; Fax:+86 755-26536141,E-mail address:szulyj@sohu.com
}

\begin{abstract}
Electric power, steam and chilled water were consumed in beer brewing process. The process is intensive in energy conversion and utilization. The brewery wastewater can generate biogas of high methane content through anaerobic sludge fermentation. This high concentrated biogas could be an excellent choice employed in energy conversion and utilization. The reclaimed water, after proper treatment, could be employed to scrub $\mathrm{CO}_{2}$ and $\mathrm{H}_{2} \mathrm{~S}$ in biogas. Through compression, the purified biogas could be stored as fuel for mechanical operation and further incorporated into the municipal LNG pipe network. According to biogas yield and energy requirements in breweries, energy usage efficiency and configuration of device for biogas Integrated Energy System (IES) were investigated. This paper introduced an Otto cycle internal combustion engine using biogas for power generation. With the biogas yield of $34.84 \mathrm{~m}^{3} / \mathrm{h}$ (standard state), the power efficiency of $28.45 \%$ could be generated with electricity of $70.0 \mathrm{~kW}$. Efficiency of combined heating and power (CHP) can reach $61.80 \%$ employing the excess heat of the engine exhaust. There are successful examples of combined cooling and power $(\mathrm{CCP})$, combined cooling and heating $(\mathrm{CCH})$ that has efficiency of over $60 \%$.
\end{abstract}

Keywords: Biogas produce, Purification process, IES conversion Using efficiency

\section{Introduction}

In China, Biogas is not only new energy source, but also an important aspect of sustainable development for the renewable energy. The biogas is generated by industrial wastewater or municipal solid waste through degradation process of anaerobic digestion. Consequently, heat and electricity is generated through the biogas [1]. Adopting the technology of combined cooling, heating, and power (CCHP), this is also known as trigeneration, or integrated energy system (IES). CCHP is the simultaneous production of mechanical power (often converted to electricity), heating and/or cooling from one primary fuel, and is an extension of CHP (combined heat and power, also defined as cogeneration) by coupling with thermally activated cooling technologies that take the waste heat from CHP for producing cooling [2].

Moving parts of internal combustion engines and gas turbine contacts directly with burning gas, there need cleaner fuels, biogas as a biomass energy source by the removal of $\mathrm{CO}_{2}$ and $\mathrm{H}_{2} \mathrm{~S}$ and combined with high conversion efficiency, low emission rates, suitable for CHP, $\mathrm{CCH}$ and $\mathrm{CCP}$ technology. Medium and small-scale units high exhaust temperature, heat recovery of flue gas is conducive to heat (cold) output, and improve unit efficiency.

Because the biogas contains a large share of the inert gas, emissions of oxides of nitrogen (NOx) were reduced relative to natural gas, while unburned hydrocarbons $(\mathrm{CH})$ were increased, and exhibit penalties of performance compared with spark ignition engine of natural gas or gasoline [3].

Kautz et al. [4] studied a $100 \mathrm{~kW}$ gas turbine recuperative cycle of exhaust to heat air and the influence of low calorific biogas on the combustion air ratio. Kim et al. [5] studied regenerative Brayton cycle using gas turbine recycling exhaust heat. Nwafor [6] examined the impact of advanced injection timing on the emission characteristics of dual-fuel engine. 
Ahead of injection timing was intended to compensate for longer ignition delay and slower burning rate of fuelled natural gas engine, and there was a s lightly increase in the oil consumption accompanied with reduced emission of $\mathrm{CO}$ and $\mathrm{CO}_{2}$.

Smith et al. [7] introduced an innovative domestic scale combined heat and power (CHP) plant incorporating a heat pump (HP). HP incorporating enhanced economy efficiency of domestic use of CHP equipment and satisfied flexibility of the family energy requirements.

Biogas was compressed to gather energy density and reduce storage capacity, the best method is biogas purified, then to compress [8]. For example, in New Zealand, both gas compressor and gas scrubber used in conjunction with, in Belgium, biogas produced from the livestock manure is being dried, scrubbed, compressed and stored in a steel tank with pressure of 4 bar in $0.2 \mathrm{~m}^{3}$, so that is alternative fuels for $\mathrm{CNG}$ (compressed natural gas), gasoline, diesel and LPG (liquefied petroleum gas) [9].

\section{Biogas process and energy demand in breweries}

\subsection{Biogas process}

Brewery wastewater comes from various procedures, such as the cleaning process of the malt production, brewing, bottling, and the wastewater from cleaning the recycled beer bottle and the packaging sterilization, as well as the overflow, disqualified product, and filter back wash water. This wastewater is rich in carbohydrates, pectin, mineral salts, cellulose etc. Therefore, it is an organic wastewater with high $\mathrm{BOD}_{5}$ and COD.

Aeration pond method is the application of biological treatment earlier; because of aerobic bacteria have an allergic reaction to load fluctuations, not to deal with high carbohydrate and volatile components of beer wastewater. Use of the up-flow anaerobic sludge blanket (UASB) has a feature that of high organic loading, short hydraulic retention time, no filler in reactor, no sludge return and stirring device, low operation cost, can be inoculated directly with the sludge particles to produce biogas etc., and that is a wastewater treatment technology for sustainable development. It can not meet emission standards used alone. In most cases, the first need to treat beer wastewater by anaerobic digestion, the most of high concentration organic wastewater in UASB was degraded, and then, under the aerobic environment oxidize and decompose low concentration of pollutants in wastewater.

Fig. 1 shows the brewery wastewater processing units and biogas generation set. The brewery wastewater discharged from workshop flows to the sump. Most of suspensions in waste water filter through the sieve grid. The pretreatment pool is necessary for wastewater with unqualified temperature and other physical/chemical conditions. Subsequently, the wastewater flows through the balance pool with the $\mathrm{pH}$ values adjusted by acid, alkali or $\mathrm{FeCl}_{3}$. The adjusted water is pumped to UASB reactor in the reaction pool to decompose the organic first into acids, then to methane and $\mathrm{CO}_{2}$. The three phase separator on top of the reactor could separate the biogas, mud and wastewater efficiently. Meanwhile, the methane bacteria could be effectively retained. The biogas is collected in gas tank after adsorption of $\mathrm{H}_{2} \mathrm{~S}$ through activated carbon. After anaerobic treatment, COD of beer wastewater dropped from about 2500 to $500 \mathrm{mg} / \mathrm{L}$. The use of air blower aerate for further processing in the aeration tank. Wastewater COD reduced to about $50 \mathrm{mg} / \mathrm{L}$ and then flow into the sediment pool. After suspended solid of aerobic fermentation were filtered, the reclaimed water qualified discharged to the sewer. 


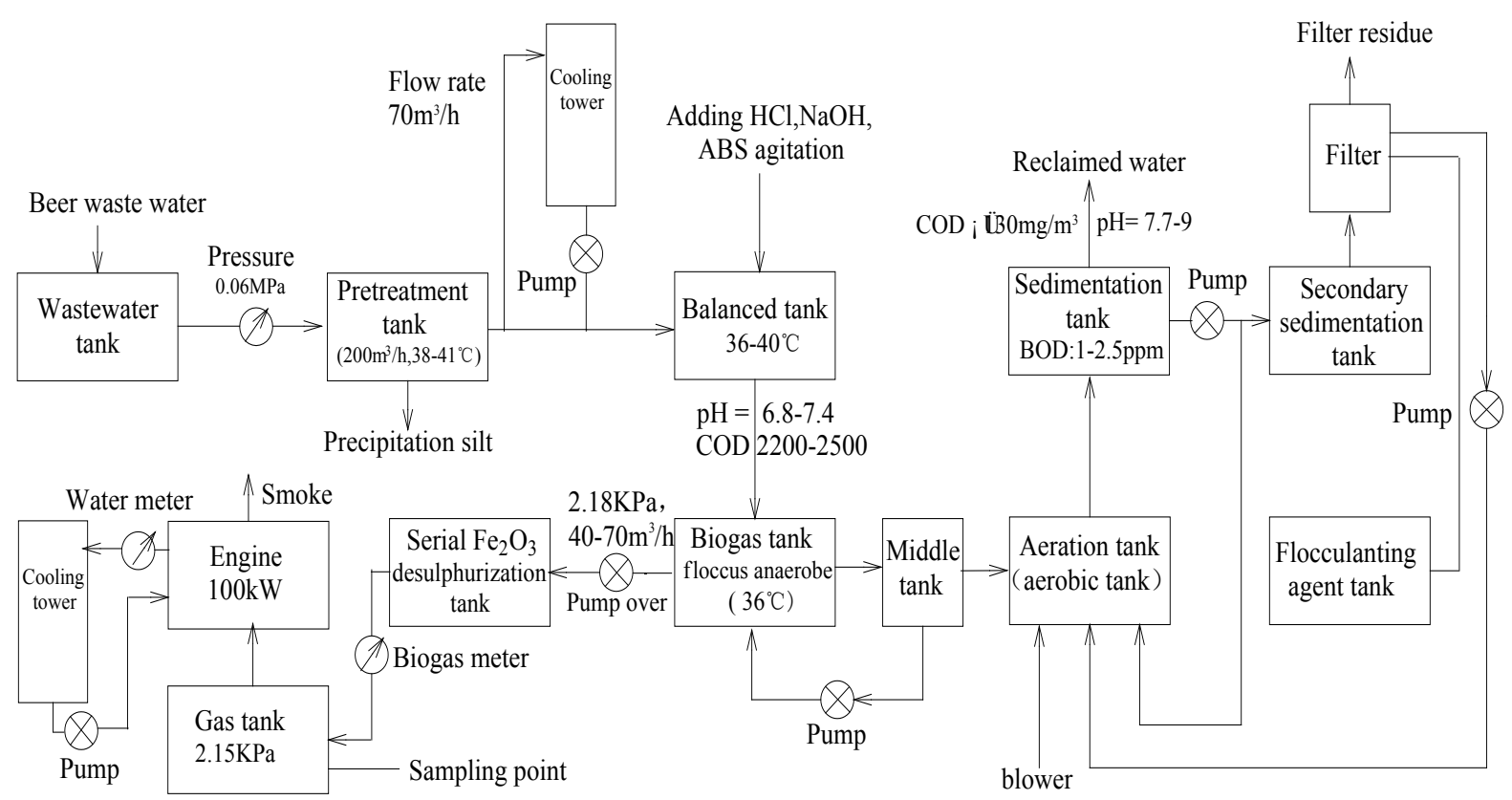

Fig.1. Schematic diagram of processing organic wastewater and generate electricity sets.

\subsection{Energy requirement}

The brewing process consumes a lot of electricity, steam and chilled water. This process is an intensive process of energy conversion and utilization. Therefore, energy consumption cost accounts for a large proportion of the production cost. Power workshop has $2 \mathrm{~s}$ ets of $25 \mathrm{t}$ steam saturated boiler (burning oil and/or natural gas), steam pressure 7.0-8.0bar. $3 \mathrm{sets}$ of ammonia compression refrigerator, cooling capacity of $496 \mathrm{RT}$, evaporator pressure of $3.7 \mathrm{bar}$, chilled water supply $4^{\circ} \mathrm{C}$, return $9^{\circ} \mathrm{C}$. Fig. 2 is energy flow diagram of steam and chilled water.

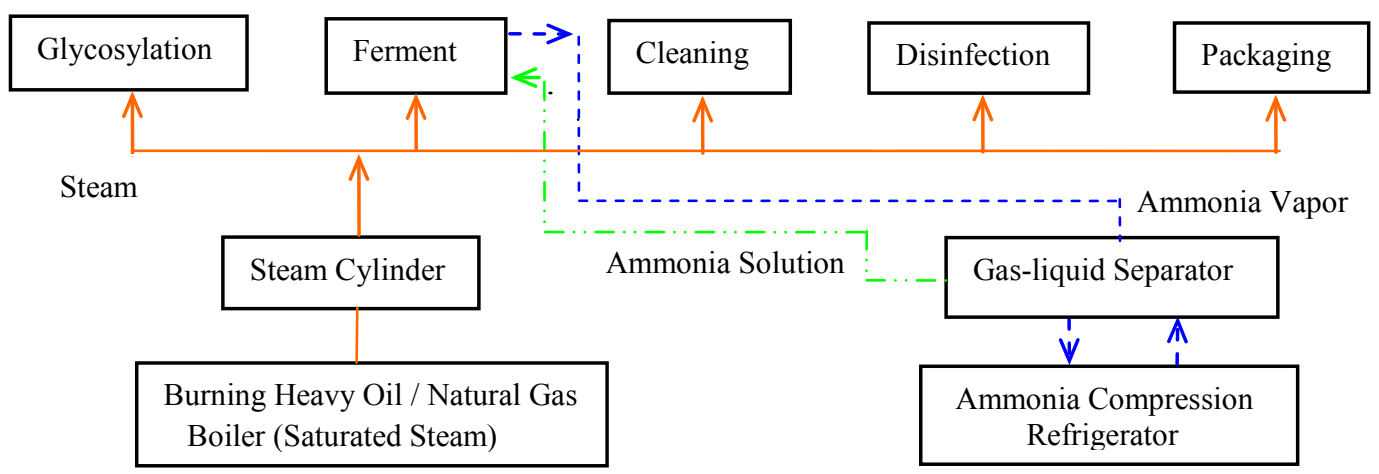

Fig.2. Energy flow diagram of steam and chilled water in breweries.

\section{Status of biogas utilization}

Shenzhen Kingway brewery ( 2 plants) and Shenzhen Tsingtao-Asahi brewery could treat beer brewery wastewater of $80-120 \mathrm{~m}^{3}$. The amount of biogas produced is $35-60 \mathrm{~m}^{3}$ (maximum volume of $80 \mathrm{~m}^{3}$ ) per hour with the measured methane content of $71.2 \%$. Table 1 shows the biogas composition with low heat value of about $25426 \mathrm{~kJ} / \mathrm{Nm}^{3}$ and thermal capacity produced as $282.51-423.77 \mathrm{~kW}$ per hour. Biogas power generation has been running for 1 year period, in order to prevent greenhouse gas emissions before it is used by the torch burning. The heat demand of beer production process provides a choice for biogas CHP and CCHP. 


\subsection{Engine power generation}

Ignition engine was used for power generation in Shenzhen Kingway brewery, Table 2 was the spark ignition engine specifications. Biogas after the removal of $\mathrm{H}_{2} \mathrm{~S}$ could be generating $70 \mathrm{~kW}$ (field test) per hour, efficiency of power generation was $28.45 \%$. Table 3 was Composition of engine exhaust for the actual measurement.

Table1. Composition of the biogas

\begin{tabular}{cccc}
\hline Component & Content (\%) & Component & Content (\%) \\
\hline $\mathrm{CH}_{4}$ & 71.2 & $\mathrm{H}_{2} \mathrm{~S}$ & $>2500 \mathrm{ppm}$ \\
$\mathrm{CO}_{2}$ & 17.1 & $\mathrm{H}_{2} \mathrm{O}_{2} \mathrm{H}_{2}$ & 2.0 \\
$\mathrm{O}_{2}$ & 2.39 & $\mathrm{~N}_{2} *$ & 7.31 \\
\hline
\end{tabular}

* Air has leaked into biogas collection cavity over the silt anaerobic digestion pond.

Table2. Specification of 4 strokes and spark ignition engine.

\begin{tabular}{lclc}
\hline \multicolumn{1}{c}{ Engine model } & Q6135DA $_{1}$ & Generator model & 90GFTA $_{1}$ \\
\hline Rated power $(\mathrm{kW})$ & 83 & Rated power $(\mathrm{kW})$ & 80 \\
Rated speed $(\mathrm{rpm})$ & 1500 & Rated speed $(\mathrm{rpm})$ & 1500 \\
Arrangement/cylinder bore $(\mathrm{mm})$ & $6 \mathrm{~L} / 135$ & Rated voltage $(\mathrm{V})$ & 400 \\
Displacement $(\mathrm{L})$ & 12.9 & Nominal current $(\mathrm{A})$ & 162 \\
Compression ratio & 10.5 & Nominal frequency $(\mathrm{Hz})$ & 50 \\
Poston travel $(\mathrm{mm})$ & 150 & Power factor & 0.8 \\
Exhaust temperature $\left({ }^{\circ} \mathrm{C}\right)$ & $\leq 630$ & Fuel gas consumes $\left(\mathrm{m}^{3} / \mathrm{kW} \mathrm{h}\right)$ & $\leq 0.33$ \\
\hline
\end{tabular}

Table3. Composition of the exhaust gas (volume percent).

\begin{tabular}{lccc}
\hline \multirow{2}{*}{ Item } & \multirow{2}{*}{ Test value } & \multicolumn{2}{c}{ Reference value } \\
\cline { 3 - 4 } $\mathrm{O}_{2}(\%)$ & 6.24 & $0.3-0.8$ & $2.0-18.0$ \\
$\mathrm{CO}_{2}(\%)$ & 8.36 & $5.0-12.0$ & $1.0-10.0$ \\
$\mathrm{NO}(\mathrm{ppm})$ & 1793 & & \\
$\mathrm{NOx}(\mathrm{ppm})$ & 1883 & $10^{5}-0.5 \times 10^{5}$ & $10^{3}-0.4 \times 10^{5}$ \\
$\mathrm{SO}_{2}(\mathrm{ppm})$ & $32-0$ & & \\
$\mathrm{H}_{2} \mathrm{O}(\%)$ & $\sim 8.8$ & $3.0-5.5$ & $0.5-4.0$ \\
$\mathrm{~N}_{2}(\%)$ & $\sim 76.6$ & $74-77$ & $76-78$ \\
\hline
\end{tabular}

* Reference value from Table 4 of reference [10]

\subsection{Heating boiler}

There is a biogas fired boiler (model: FBA-080 F) in Shenzhen Tsingtao-Asahi Brewery with the parameters as follows: rated pressure: $\mathrm{P}=1.04 \mathrm{MPa}$ (saturated steam), the amount of steam produced $1.25 \mathrm{t} / \mathrm{h}$, e xhaust temperature $300^{\circ}$, biogas/ steam ratio $=2: 1$, boiler efficiency $\eta=80 \%$. The actual operation pressure was $0.6 \mathrm{MPa}$.

\section{Biogas processing}

Because high temperature of biogas fire, slower burning speed, serious ignition delay and higher exhaust temperature, all that resulting in lower efficiency of biogas power generation. biogas purification (removal of $\mathrm{CO}_{2}$ and $\mathrm{H}_{2} \mathrm{~S}$ ), then compressed and stored as alternative 
products of CNG, gasoline, diesel and LPG, showing the goods value of biogas through the transport.

\subsection{Gas purification, compression and storage}

Removal of $\mathrm{H}_{2} \mathrm{~S}$ in the biogas can be divided into (1) dry and oxidation,(2) ferric oxide adsorption, (3) activated carbon adsorption, and(4) liquid-phase oxidation process. A simple adsorption method using activated carbon was used in 3 breweries.

The amine solution of 10\% mono-ethanolamine (MEA) and diethanolamine (DEA) are usually used to absorb $\mathrm{CO}_{2}$. It takes $5 \mathrm{~min}$ for the solution regeneration to be completed by boiling. The newer approach is the sulfolane method or the Sulfinol method composed by alcohol amine and sulfolane adding water. Method of reclaimed water which was beer wastewater treated when water pressure increased as the absorbent to remove $\mathrm{CO}_{2}$ is the most simple and less expensive. Efficiency of the scrubber depends on that scrubber specifications, packing and gas pressure in scrubber, composition of raw biogas, the flow rate and purity of water used and so on.

The critical temperature and pressure required to liquefied biogas were: $-82.58^{\circ} \mathrm{C}$ and 47.5 bar respectively. Purification biogas compressed by the compressor, according to different pressure stored in cylinders, which could be transported with long-distance, may be also build a small scale station on side.

\subsection{Power fuel}

After $\mathrm{CO}_{2}, \mathrm{H}_{2} \mathrm{~S}$ and water vapor in biogas were removed, the methane ( $>90 \%$, heat value equivalent to LNG), could be compressed and stored as fuel for car and other power machines. Table 4 is data of LNG imported to Guangdong province of China from Australia, kindly provided by the Shenzhen Gas Group.

Table 4. Data of physical and chemical for $L N G$.

\begin{tabular}{lclc}
\hline Composition & $(\%)$ & Data $\left(0^{\circ} \mathrm{Clatm}\right)$ & Value \\
\hline $\mathrm{CH}_{4}$ & 87.59 & HHV $\left(\mathrm{MJ} / \mathrm{Nm}^{3}\right)$ & 45.08 \\
$\mathrm{C}_{2} \mathrm{H}_{6}$ & 8.13 & LHV $\left(\mathrm{MJ} / \mathrm{Nm}^{3}\right)$ & 40.71 \\
$\mathrm{C}_{3} \mathrm{H}_{8}$ & 3.2 & Density $\left(\mathrm{kg} / \mathrm{Nm}^{3}\right)$ & 0.8318 \\
$\mathrm{C}_{4} \mathrm{H}_{10}$ & 0.99 & Specific volume $\left(\mathrm{Nm}^{3} / \mathrm{t}\right)$ & 1202 \\
$\mathrm{C}_{5} \mathrm{H}_{12}$ & 0.05 & LHV $(\mathrm{MJ} / \mathrm{kg})$ & 48.92 \\
\hline
\end{tabular}

Use of CNG instead of gasoline as a motor fuel, the emissions of $\mathrm{CO}, \mathrm{CH}$ compounds and $\mathrm{NO}$ compounds can be decreased by $97 \%, 72 \%$, and $39 \%$ respectively. Performance of resistance to blast for $\mathrm{CNG}$ equivalent to gasoline is about octane number of 130 , and $\mathrm{CNG}$ does not release lead, benzene and other toxic substances all which can cause cancer. Forklift which using LPG as fuel made by Japan Fuji Co. in Shenzhen Tsingtao-Asahi brewery, may also use purified biogas as a substitute.

\subsection{Incorporate into $L N G$ pipe network}

Due to lower productive rate of biogas, gas source instability, lower energy carrier demand load, difficult to manufacture equipment and operation and a long payback time as investment etc., biogas can no effectively use in the IES, so that, it could be considered incorporate into the municipal LNG Network pipe after the quality checked up. 


\section{Integrated energy system (IES) of biogas}

Electricity is the high grade energy. According to the second law of thermodynamics, the electricity generated by biogas is of the highest efficiency, meanwhile, the exhaust gas could be employed for heating or cooling. IES of biogas would adopt the following technologies such as Otto cycle of ignition engine, Brayton cycle of gas turbine, power generation of fuel cells, absorption and adsorption refrigeration, high efficient combustion, high efficiency removal of $\mathrm{H}_{2} \mathrm{~S}$ and $\mathrm{CO}_{2}$, as well as recovery and storage for thermal energy.

\subsection{CHP project}

Project 1: Engine + Heat tube exchanger of condensation type

(Shenzhen Kingway brewery)

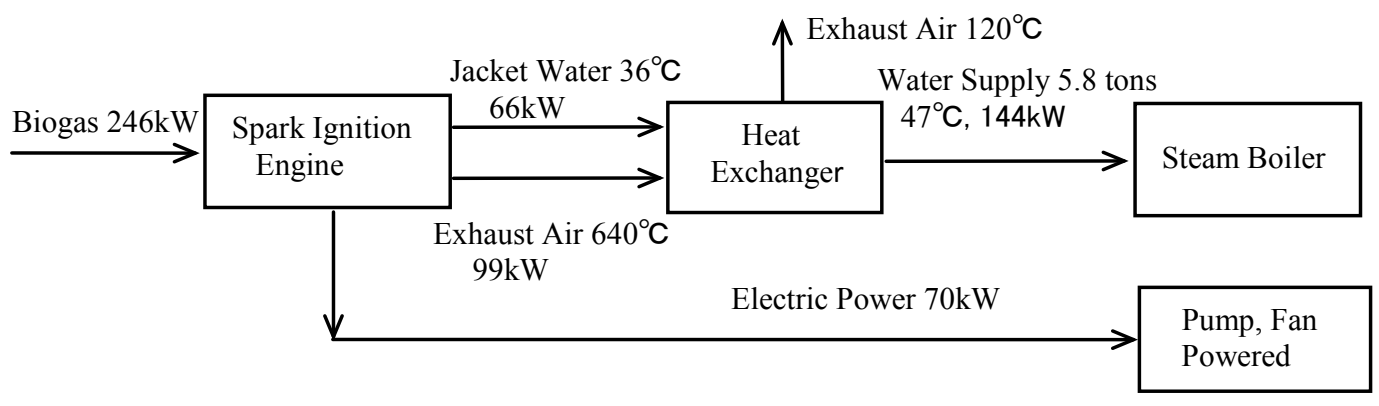

- Spark Ignition Engine of biogas fueled without removal of $\mathrm{CO}_{2}$, generate electricity efficiency of $28.45 \%$, discharged heat of $99 \mathrm{~kW}$ by engine exhaust and of $66 \mathrm{~kW}$ by jacket cooling water, dispersed heat of $2.8 \mathrm{~kW}$ by convection and of $4.6 \mathrm{~kW}$ by radiation.

- If heat of engine exhaust was utilized through heat tube heat exchanger to heat water supply and temperature was reduced to about $120^{\circ} \mathrm{C}$, then, overall CHP efficiency may be reached $61.8 \%$, and engine exhaust even could be discharged at the condensation temperature of $57^{\circ} \mathrm{C}$.

\subsection{CCP project [11]}

Project 2: Micro Turbine (Honeywell) + Direct fired double effect chiller

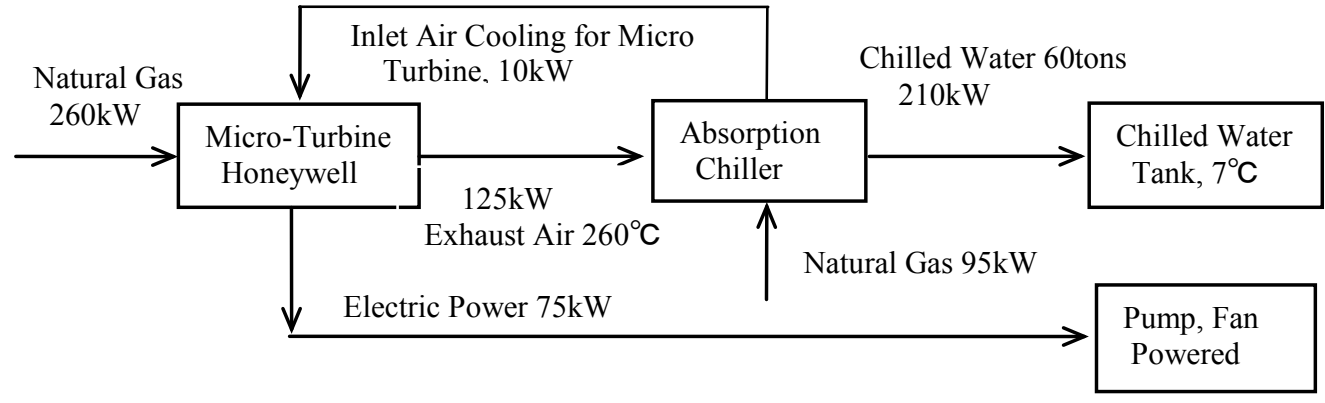

- Turbine efficiency $28.75 \%$. Inlet air cooled to $16^{\circ} \mathrm{C}$ to keep constant capacity of turbine.

- Broad absorption chiller using lithium bromide-water, direct fired double effect chiller with COP of 1 . Chilled water temperature: supply $7.8-9.4^{\circ} \mathrm{C}$, return $12.814 .4^{\circ} \mathrm{C}$

Performance of MT Honeywell and absorption chiller were shown in Table 5 and Table 6. 
Table 5. Performance parameters of MT (Honeywell).

\begin{tabular}{lcc}
\hline \multicolumn{1}{c}{ Item } & Parameter & \\
\hline Rating power $(\mathrm{kW})$ & 75 & $15^{\circ} \mathrm{C}, 1 \mathrm{~atm}$ \\
NG wastage $\left(\mathrm{m}^{3} / \mathrm{h}\right)$ & 27 & $\geq 0.62 \mathrm{MPa}($ absolute $)$ \\
Thermoelectricity efficiency $(\%)$ & 28.5 & $15^{\circ} \mathrm{C}, 1 \mathrm{~atm}$ \\
Exhaust temperature $\left({ }^{\circ} \mathrm{C}\right)$ & 280 & \\
Exhaust flux $(\mathrm{kg} / \mathrm{s})$ & $0.67 / 0.76$ & \\
Emission of $\mathrm{NO}_{\mathrm{X}}(\mathrm{ppm})$ & $<13$ & $15^{\circ} \mathrm{C}, 1 \mathrm{~atm}$, full load \\
\hline
\end{tabular}

Table 6. Broad LiBr absorption chillers (Mode: BD7N280-15).

\begin{tabular}{lclc}
\hline \multicolumn{1}{c}{ Item } & Parameter & \multicolumn{1}{c}{ Item } & Parameter \\
\hline Capacity of refrigeration (USRT) & 23 & Produce heat $(\mathrm{kW})$ & 114 \\
Chilled water outlet/inlet temp. $\left({ }^{\circ} \mathrm{O}\right)$ & $6.7 / 12.2$ & Warm water outlet temp. $\left({ }^{\circ} \mathrm{O}\right)$ & 50 \\
Chilled water flux $\left(\mathrm{m}^{3} / \mathrm{h}\right)$ & 12.8 & Warm water flux $\left(\mathrm{m}^{3} / \mathrm{h}\right)$ & 19.6 \\
Cooling water outlet $/$ inlet temp. $\left({ }^{\circ} \mathrm{O}\right)$ & $36 / 29.4$ & Inlet temp. of exhaust $\left({ }^{\circ} \mathrm{O}\right)$ & 280 \\
Cooling water flux $\left(\mathrm{m}^{3} / \mathrm{h}\right)$ & 24.3 & Match electricity $(\mathrm{kW})$ & 1.2 \\
\hline
\end{tabular}

Project 3: Micro Turbines (Capstone) + Single effect chiller

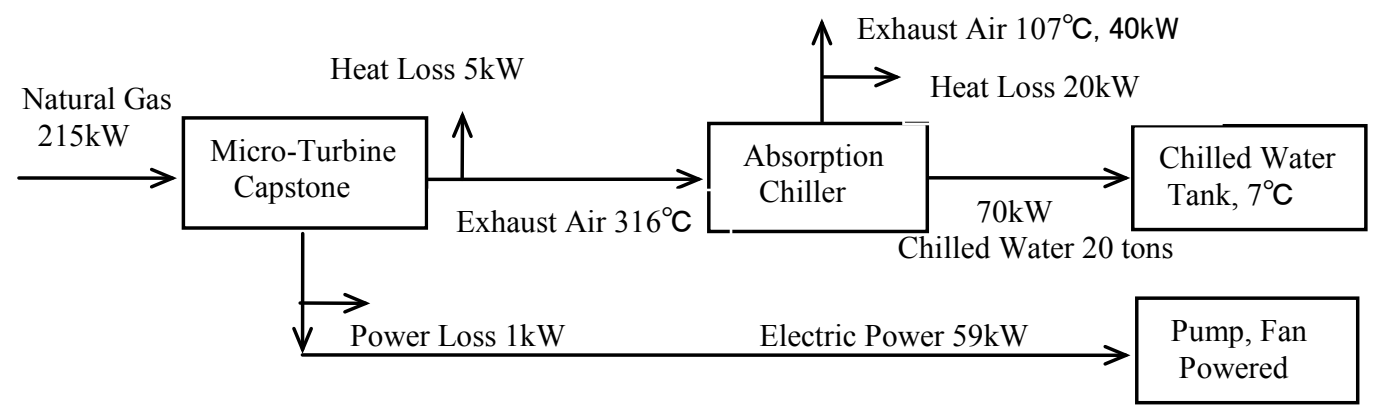

- MT Capstone efficiency 27.9\%, with chiller 63.5\%. Average exhaust inlet temp.C271 , outlet temp. $113^{\circ} \mathrm{C}$.

- Broad absorption chiller driven only by MT exhaust. Single effect chiller with COP of 0.7, nominal capacity of chilled water is 20 tons. Parasitic power is $6.4 \mathrm{~kW}$.

\subsection{CCH project}

Project 4: Engine driven Goettl Units + Heat tube exchanger of condensation type

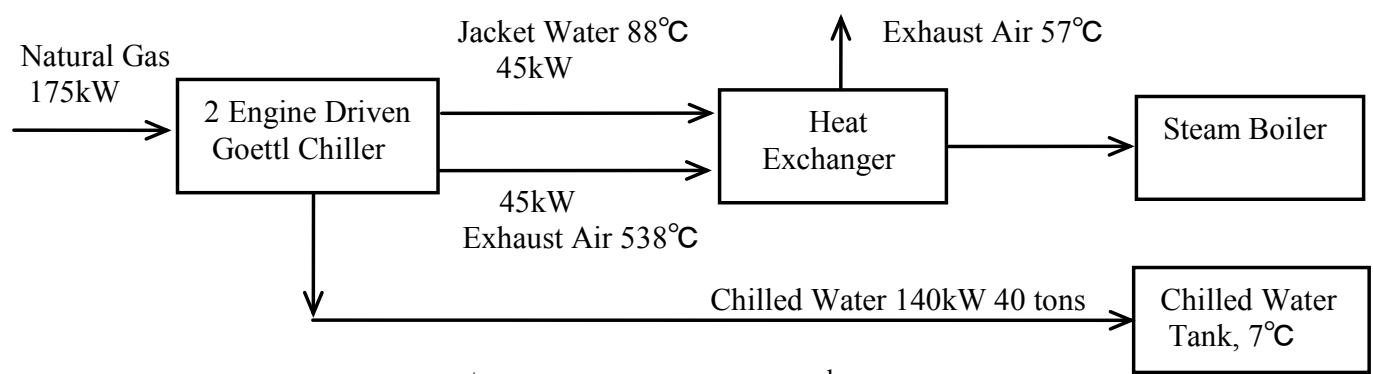

- Engine Driven Goettl Units. $1^{\text {st }}$ stage $\mathrm{COPG}=1.4,2^{\text {nd }}$ stage $\mathrm{COPG}=0.8$, Engine output $52 \mathrm{~kW}$, engine efficiency $30 \%$. 


\section{Conclusion}

This paper introduced and analyzed biogas utilization for the three large modern breweries, which is not perfect and irrational for use of biogas energy. Based on the current biogas technology and equipments, accordingly to the biogas yield and energy demand in breweries, analyzed and studied the energy utilization technology, equipment configuration, and conversion efficiency on the integrated energy system (IES). The biogas purification process employs qualified reclaimed water from wastewater treated of the brewery to scrub $\mathrm{CO}_{2}$ and $\mathrm{H}_{2} \mathrm{~S}$ in biogas. This process is simple with low operation cost. The resultant biogas is rich in methane content and efficient to improve the efficiency of IES. Both electricity generation and heating efficiency, as well as the cooling efficiency can reach as high as $60 \%$.

\section{Acknowledgements}

This work was supported by public technological project of the Bureau of Science, Technology and Information of Shenzhen city, under Contract No.SY2008343.

\section{References}

[1] Pöschl M, Ward S, Owende P. Evaluation of energy efficiency of various biogas production and utilization pathways. Applied Energy. 87, 2010, pp. 3305-3321.

[2] Deng J, Wang RZ, Han GY. A review of thermally activated cooling technologies for combined cooling, heating and power systems. Progress in Energy and Combustion Science. 37, 2011, pp. 172-203.

[3] Crookes RJ. Comparative bio-fuel performance in internal combustion engines. Biomass and Bioenergy. 30, 2006, pp. 461-468.

[4] Kautz M, Hansen Ulf. The externally-fired gas-turbine (EFGT-Cycle) for decentralized use of biomass. Applied Energy. 84, 2007, pp.795-805.

[5] Kim KH, Perez-Blanco H. Potential of regenerative gas-turbine systems with high fogging compression. Applied Energy. 84, 2007, pp.16-28.

[6] Nwafor OMI. Effect of advanced injection timing on emission characteristics of diesel engine running on natural gas. Renewable Energy. 32, 2007, pp.2361-2368.

[7] Smith MA, Few PC. Domestic-scale combined heat-and-power system incorporating a heat pump: analysis of a prototype plant. Applied Energy. 70, 2001, pp. 215-232.

[8] Osorio F, Torresba JC. Biogas purification from anaerobic digestion in a wastewater treatment plant for biofuel Production. Renewable Energy. 34, 2009, pp. 2164-2171.

[9] Kapdi SS, Vijay VK, Rajesh SK, Rajendra Prasad. Biogas scrubbing, compression and storage: perspective and prospectus in Indian context. Renewable Energy. 30, 2005, pp. $1195-1202$.

[10] Coronado CR, Carvalho JA, Yoshioka JT, Silveira JL. Determination of ecological efficiency in internal combustion engines:the use of biodiesel. Applied Thermal Engineering. 29, 2009, pp. 1887-1892.

[11]Garland PW.CHP for buildings integration: test centers at ORNL and University of Maryland. Oak Ridge National Laboratory, http:/www.ornl. gov/sci/eere/PDFs/ garland_seminar.pdf; 2003. 